\title{
A Student-Oriented Study: Analyzing the Relationship between Happiness and Satisfaction with Life
}

\author{
Veli Ozan Çakır (Corresponding author) \\ Departmant of Sports Management \\ İstanbul University-Cerrahpasa, Istanbul, Turkey \\ E-mail: ozancakir@istanbul.edu.tr \\ Duygu Harmandar Demirel \\ Departmant of Physical Education and Sports \\ Necmettin Erbakan University, Konya, Turkey \\ E-mail: duyguharmandar@gmail.com
}

Received: April 15, 2019 Accepted: May 20, 2019 Published: May 28, 2019

doi:10.5296/jei.v5i1.14661ＵRL: https://doi.org/10.5296/jei.v5il.14661

\begin{abstract}
The purpose of this study is to analyse the happiness and life satisfaction levels of university students by various factors and to reveal the relationship between those two terms. The sample group of the study is composed of Necmettin Erbakan University Physical Education and Sports Teacher Department and Pamukkale University Sports Sciences Faculty students, who are 801 in number, 394 of them male and 407 of them female, and with an average age of $23.58 \pm 2.98$. In the study the "Life Satisfaction Scale," which has been developed by Diener et al. (1985) and adapted to Turkish by Durak et al. (2010), and the "Oxford Happiness Scale Short Version," which has been developed by Hills and Argyle (2002) and adapted to Turkish by Doğan and Akıncı Çötok (2010), has been used. To determine the personal information distribution of participants percentage and frequency methods, and to determine whether the data has normal distribution or not Shapir Wilks normalcy test has been used and after establishing that the data is suitable for parametric test conditions, to analyse the data the independent $t$ Test, Anova and Pearson Correlation tests have been used. According to the analysis results, a significant difference in life satisfaction has been observed with respect to age and regular exercise parameters $(\mathrm{p}<0.05)$. According to the happiness scale a significant difference has been observed with respect to gender, department,
\end{abstract}


grade and department satisfaction parameters $(p<0.05)$. Finally, a positive and meaningful relationship has been observed between the two scales. Consequently, it could be argued that life satisfaction and happiness levels of participants show significant differences with respect to some parameters and that the higher their life satisfaction, the higher their level of happiness.

Keywords: University students, Satisfaction with life, Oxford happiness

\section{Introduction}

Throughout human history it has been believed that the search for happiness has been the most fundamental motivation for individuals (Diener, 1984). Today we often run into many problems in daily life and it is an important virtue to think that "there is an easy part to everything difficult" and to have an optimistic perspective. Life is filled with challenges and struggles and therefore being flexible and to have a positive wish to learn is quite important for our lives. Ryan and Deci (2001), claim that the psychological welfare, which comes with order in daily life, can be explained with just one concept, '(hedonic) happiness.' Happiness, as the most important phenomenon, which humans throughout history pursued and sought to obtain by various methods, has been directly or indirectly discussed in mythology, philosophy, literature and more or less in all forms of art. The attempt at defining what happiness is and formulating how an individual can obtain it is to be found in many researches and theories concerning human behaviour and mental health (Sahranç, 2007).

Happiness is a concept, which surrounds an individual in all its aspects, i.e. psychologically, physiologically, cognitively, socially and so on (Çakıcı, 2015). Happiness is defined as the cognitive and perceptive evaluation of life. Thus, it has been suggested that having positive feelings such as joy, pride, trust, excitement etc. often and having negative feelings such as rage, fear, worry, hate etc. rarely and to have high satisfaction from various fields of life (family life, work life, career etc.) point to happiness (Çakıcı, 2015; Diener, 1984; Diener et al., 1985). In this context the one of the main elements in being happy and leading a meaningful life is having a satisfactory life and human race has been interested in it for centuries.

Life could be defined as the total time spent at work and off work and life satisfaction is the emotional response or attitude to the time spent at work, off work and other off work activities (Dikmen, 1995). It points to a cognitive/attitudinal process and could be defined as a general evaluation of individuals' life quality within the standards of their own choosing (Shin \& Johnson, 1978; Diener, Emmons, Larsen, \& Griffin, 1985). Life satisfaction, which is key to a happy and meaningful life, is a general evaluation of life quality based on a person's choices (Diener, 1984). It also involves past, current and future satisfaction, the wish to change one's life and what a person's close friends and relatives think about that person's life. The sphere of satisfaction contains work, leisure time, family, personality, health and the person's immediate environment (Diener et al., 1999; Appleton and Song, 2008).

Veenhoven (1996) defines life satisfaction as the positive improvement degree of the quality of life as a whole and suggests that changes in life (quality of society, a person's place in that 
society, personal skills), state of affairs, being experienced (function of hedonic experience, to love or not to love, inner generation of feelings, the capacity to like), inner advance of progress (to calculate or draw results, meanings underlying feelings, differences in living environment and the differences in the improvement of the whole), frame the relationship between life satisfaction and sphere of satisfaction.

Today teachers, who are seen as doing a holy and valuable work, still have a direct impact on individuals, who comprise society. At this point the qualities of teachers gain importance and within educational bounds this issue becomes paramount to dwell upon. Since teachers mould their students in every field of life, the students are primarily influenced by their teachers. From this perspective it is of great importance that the teachers, who have immense influence on society as a whole, should be mentally and psychologically healthy. Teachers need to have a positive view towards themselves, the individuals around them who they are in contact with, their students and to life as a whole. In this context the purpose of this study is to survey the relationship between the life satisfaction and happiness levels of university students.

\section{Method}

\subsection{Research Model}

In this study survey model has been used. Survey model seeks to portray a past or current situation as it was or is, to define an event, an individual or an object on its own terms, and to observe it without trying to change current conditions (Karasar, 2012).

\subsection{Sample Group}

The sample group has been chosen by non-probability purposive sampling method among Necmettin Erbakan University PE and Sports Teacher Department and Pamukkale University Sports Sciences Faculty students, who are 801 in total, of which 394 are male and 407 female, and with an average age of $23.58 \pm 2.98$.

\subsection{Data Collection Tools}

In this study, "Personal Information Form," "Life Satisfaction Scale," and "Oxford Happiness Scale (Short Version)" have been used as data collection tools.

\subsubsection{Personal Information Form}

"Personal Information Form," which has been developed by the surveyors has been used to obtain information from the participants, such as gender, department, grade, department satisfaction and engagement in sports.

\subsubsection{Life Satisfaction Scale}

To determine the life satisfaction of participants "Life Satisfaction Scale," which has been developed by Diener et al. (1985) and adapted to Turkish, rendered legitimate and credible by Durak et al. (2010). It is a 5-point Likert Scale $(1=\mathrm{I}$ absolutely agree, $5=\mathrm{I}$ absolutely disagree) with five articles and one dimension. 


\subsubsection{Oxford Happiness Scale-Short Version}

To estimate the happiness level of participants "Oxford Happiness Scale Short Version," which has been developed by Hills and Argyle (2002), and adapted to Turkish by Doğan and Akıncı Çötok (2010), has been used. Oxford Happiness Scale is comprised of a single sub dimension and 7 expressions. The 5-point Likert Scale expressions are answered with; (1) I absolutely disagree-(5) I absolutely agree.

\section{Findings}

Table 1. Distribution of participants' personal information

\begin{tabular}{|c|c|c|c|}
\hline Parameters & & $\mathrm{F}$ & $\%$ \\
\hline \multirow{3}{*}{ Gender } & Male & 394 & 49.2 \\
\hline & Female & 407 & 50.8 \\
\hline & Total & 801 & 100 \\
\hline \multirow{5}{*}{ Age } & $17-20$ & 151 & 18.9 \\
\hline & $21-23$ & 426 & 53.2 \\
\hline & $24-26$ & 168 & 21.0 \\
\hline & 27 and over & 56 & 7.0 \\
\hline & Total & 801 & 100 \\
\hline \multirow{5}{*}{ Department } & Recreation & 335 & 41.8 \\
\hline & PE Teacher & 187 & 23.3 \\
\hline & Coaching & 119 & 14.9 \\
\hline & Sports Management & 160 & 20.0 \\
\hline & Total & 801 & 100 \\
\hline \multirow{5}{*}{ Grade } & Freshman & 132 & 16.5 \\
\hline & Sophomore & 128 & 16.0 \\
\hline & Junior & 216 & 27.0 \\
\hline & Senior & 325 & 40.6 \\
\hline & Total & 801 & 100 \\
\hline \multirow{3}{*}{ Department Satisfaction } & Yes & 625 & 78.0 \\
\hline & No & 176 & 22.0 \\
\hline & Total & 801 & 100 \\
\hline \multirow{3}{*}{ Regular Engagement in Sports } & Yes & 463 & 57.8 \\
\hline & No & 338 & 42.2 \\
\hline & Total & 801 & 100 \\
\hline
\end{tabular}




\section{Macrothink $\Lambda$ Institutem}

Table 1 displays the statistical findings of participants with reference to their genders, ages, departments, grades, department satisfactions and regular engagements in sports. Analysis shows that of the participants; $50.8 \%$ are "Female" and $49.2 \%$ are "Male," $53.2 \%$ are "between the ages of 21 and 23," 41.8\% study "Recreation," $40.6 \%$ are "Seniors," $78.0 \%$ are "Satisfied" with their department, and 57.8\% are "Regularly Engaged in Sports."

Table 2. Life Satisfaction Scale with respect to participants' genders, t Test results

\begin{tabular}{|l|l|l|l|l|l|}
\hline Scale & Gender & $\mathrm{N}$ & Avg. \pm Sd. & $\mathrm{t}$ & $\mathrm{P}$ \\
\hline \multirow{2}{*}{ Life Satisfaction Scale } & Male & 392 & $4.30 \pm 1.22$ & \multirow{2}{*}{7.760} & \multirow{2}{*}{.109} \\
\cline { 2 - 4 } & Female & 406 & $4.26 \pm 1.10$ & & \\
\hline
\end{tabular}

Table 2 displays t Test results with reference to genders of participants. Analysis shows, that there is no significant difference in life satisfaction levels in relation to participants' gender $(p>0.05)$. It is observed that male participants have a higher life satisfaction compared to female participants but no significant difference has been identified.

Table 3. Oxford Happiness Scale t Test results with respect to participants' genders

\begin{tabular}{|l|l|l|l|l|l|}
\hline Scale & Gender & N & Avg. \pm Sd. & t & P \\
\hline \multirow{2}{*}{ Oxford Happiness Scale } & Male & 392 & $3.68 \pm 1.85$ & \multirow{2}{*}{6.330} & \multirow{2}{*}{$.005^{*}$} \\
\cline { 2 - 4 } & Female & 406 & $3.52 \pm 1.72$ & & \\
\hline
\end{tabular}

Table 3 displays t Test results concerning their happiness levels with reference to genders of participants. Analysis shows, that there is a significant difference in happiness level of the participants in relation to the gender of the participants $(p<0.05)$. Male participants have a higher score than female participants.

Table 4. Life Satisfaction Scale ANOVA results with respect to participants' ages

\begin{tabular}{|l|l|l|l|l|l|}
\hline Scale & Age & N & Avg. \pm Sd. & F & P \\
\hline \multirow{4}{*}{ Life Satisfaction Scale } & $17-20$ & 151 & $4.25 \pm 1.33$ & & \\
\cline { 2 - 4 } & $21-23$ & 424 & $4.37 \pm 1.15$ & \multirow{2}{*}{2.486} & \multirow{2}{*}{$.050^{*}$} \\
\cline { 2 - 4 } & $24-26$ & 168 & $4.21 \pm 1.06$ & & \\
\cline { 2 - 5 } & 27 and Over & 55 & $3.96 \pm 1.94$ & & \\
\hline
\end{tabular}




\section{Macrothink}

Table 4 displays Anova test results concerning life satisfaction with respect to participants' ages. Analysis shows, that there is a significant difference in life satisfaction level with respect to participants' age $(\mathrm{p}<0.05)$. Life satisfaction level of participants between the ages of 21 and 23 is higher than that of other participants.

Table 5. Oxford Happiness Scale ANOVA results with respect to participants' ages

\begin{tabular}{|l|l|l|l|l|l|}
\hline Scale & Age & N & Avg. \pm Sd. & F & P \\
\hline \multirow{4}{*}{ Oxford Happiness Scale } & $17-20$ & 151 & $3.60 \pm 1.89$ & & \\
\cline { 2 - 4 } & $21-23$ & 424 & $3.71 \pm 1.84$ & \multirow{3}{*}{1.670} & \multirow{2}{*}{.172} \\
\cline { 2 - 4 } & $24-26$ & 168 & $3.59 \pm 1.61$ & & \\
\cline { 2 - 5 } & 27 and Over & 55 & $3.56 \pm 1.48$ & & \\
\hline
\end{tabular}

Table 5 displays Anova test results with respect to participants' ages. Analysis shows, that there is no significant difference in happiness level with respect to participants' age $(p>0.05)$. Happiness level of participants between the ages of 21 and 23 is higher than that of other participants but no significant difference has been observed.

Table 6. Life Satisfaction Scale ANOVA results with respect to participants' departments

\begin{tabular}{|l|l|l|l|l|l|}
\hline Scale & Department & N & Avg. \pm Sd. & F & P \\
\hline \multirow{4}{*}{ Life Satisfaction Scale } & Recreation & 333 & $4.31 \pm 1.07$ & & \\
\cline { 2 - 4 } & PE Teacher & 424 & $4.26 \pm 1.13$ & \multirow{3}{*}{1.179} & \multirow{2}{*}{.119} \\
\cline { 2 - 4 } & Coaching & 168 & $4.22 \pm 1.25$ & & \\
\cline { 2 - 4 } & Sports Management & 55 & $4.29 \pm 1.25$ & & \\
\hline
\end{tabular}

Table 6 displays Anova test results of life satisfaction level with respect to participants' departments. Analysis shows, that there is no significant difference in life satisfaction level with respect to participants' departments $(p>0.05)$. Life satisfaction level of students, who are studying Recreation, is higher than that of students studying other subjects but no significant difference has been observed. 
Table 7. Oxford Happiness Scale ANOVA results with respect to participants' departments

\begin{tabular}{|l|l|l|l|l|l|}
\hline Scale & Department & N & Avg. \pm Sd. & F & P \\
\hline \multirow{4}{*}{ Oxford Happiness Scale } & Recreation & 333 & $3.72 \pm 1.72$ & & \\
\cline { 2 - 4 } & PE Teacher & 424 & $3.64 \pm 1.63$ & \multirow{2}{*}{2.168} & \multirow{2}{*}{$.040^{*}$} \\
\cline { 2 - 4 } & Coaching & 168 & $3.65 \pm 1.98$ & & \\
\cline { 2 - 4 } & Sports Management & 55 & $3.53 \pm 1.91$ & & \\
\hline
\end{tabular}

Table 7 displays Anova test results of happiness level with respect to participants' departments. Analysis shows, that there is significant difference in happiness level with respect to participants' departments $(\mathrm{p}<0.05)$. Students, who are studying Recreation, have scored higher than students studying other subjects.

Table 8. Life Satisfaction Scale ANOVA results with respect to participants' grades

\begin{tabular}{|l|l|l|l|l|l|}
\hline Scale & Grade & N & Avg. \pm Sd. & F & P \\
\hline \multirow{4}{*}{ Life Satisfaction Scale } & Freshman & 135 & $4.22 \pm 1.42$ & & \\
\cline { 2 - 4 } & Sophomore & 132 & $4.43 \pm 1.22$ & \multirow{2}{*}{1.881} & \multirow{2}{*}{.450} \\
\cline { 2 - 4 } & Junior & 219 & $4.27 \pm 1.17$ & & \\
\cline { 2 - 4 } & Senior & 315 & $4.25 \pm 1.15$ & & \\
\hline
\end{tabular}

Table 8 displays Anova test results of life satisfaction level with respect to participants' grades. Analysis shows, that there is no significant difference in life satisfaction level with respect to participants' grades $(\mathrm{p}>0.05)$. Life satisfaction level of sophomore students is higher are than those in other grades but no significant difference has been observed.

Table 9. Oxford Happiness Scale ANOVA results with respect to participants' grades

\begin{tabular}{|l|l|l|l|l|l|}
\hline Scale & Grade & N & Avg. \pm Sd. & F & P \\
\hline \multirow{4}{*}{ Oxford Happiness Scale } & Freshman & 135 & $3.54 \pm 0.88$ & & \\
\cline { 2 - 4 } & Sophomore & 132 & $3.64 \pm 0.82$ & \multirow{3}{*}{3.817} & \multirow{2}{*}{$.010^{*}$} \\
\cline { 2 - 5 } & Junior & 219 & $3.42 \pm 0.91$ & & \\
\cline { 2 - 5 } & Senior & 315 & $3.53 \pm 0.61$ & & \\
\hline
\end{tabular}




\section{Macrothink}

Table 9 displays Anova test results of happiness level with respect to participants' grades. Analysis shows, that there is a significant difference in happiness level with respect to participants' grades $(p<0.05)$. Life satisfaction level of sophomore students is higher are than those in other grades

Table 10. Life Satisfaction Level t Test results with respect to participants' department satisfactions

\begin{tabular}{|l|l|l|l|l|l|}
\hline Scale & Satisfaction & N & Avg. \pm Sd. & t & P \\
\hline \multirow{2}{*}{ Life Satisfaction Scale } & Yes & 626 & $4.38 \pm 1.20$ & \multirow{2}{*}{10.857} & \multirow{2}{*}{.807} \\
\cline { 2 - 5 } & No & 172 & $4.28 \pm 1.00$ & & \\
\hline
\end{tabular}

Table 10 displays life satisfaction level t Test results with respect to participants' department satisfactions. Analysis shows, that there is no statistically significant difference in life satisfaction level with respect to participants' department satisfactions $(p>0.05)$. Those who are satisfied with their departments have a higher life satisfaction than those who are not, but no significant difference has been observed.

Table 11. Oxford Happiness Scale t Test results with respect to participants' department satisfactions

\begin{tabular}{|l|l|l|l|l|l|}
\hline Scale & Satisfaction & N & Avg. \pm Sd. & t & P \\
\hline \multirow{2}{*}{ Oxford Happiness Scale } & Yes & 392 & $3.81 \pm 0.79$ & \multirow{2}{*}{2.158} & \multirow{2}{*}{$.005^{*}$} \\
\cline { 2 - 7 } & No & 406 & $3.61 \pm 0.79$ & & \\
\hline
\end{tabular}

Table 11 displays happiness level t Test results with respect to participants' department satisfactions. Analysis shows, that there is a statistically significant difference in happiness level with respect to participants' department satisfactions $(\mathrm{p}<0.05)$. Those who are satisfied with their departments have higher scores compared to those who are not.

Table 12. Life Satisfaction Scale $\mathrm{t}$ Test results with respect to participants' regular engagement in sports

\begin{tabular}{|l|l|l|l|l|l|}
\hline Scale & Sports & N & Avg. \pm Sd. & t & P \\
\hline \multirow{2}{*}{ Life Satisfaction Scale } & Yes & 462 & $4.37 \pm 1.31$ & \multirow{2}{*}{2.541} & \multirow{2}{*}{$.011^{*}$} \\
\cline { 2 - 4 } & No & 339 & $4.16 \pm 0.90$ & & \\
\hline
\end{tabular}




\section{Macrothink}

Table 12 displays life satisfaction level t Test results with respect to participants' engagement in sports. Analysis shows, that there is no statistically significant difference in life satisfaction level with respect to participants' regular engagement in sports $(p<0.05)$. Those who are regularly engaged in sports have higher scores compared to those who are not.

Table 13. Oxford Happiness Scale $\mathrm{t}$ Test results with respect to participants' regular engagement in sports

\begin{tabular}{|l|l|l|l|l|l|}
\hline Scale & Sports & $\mathrm{N}$ & Avg. \pm Sd. & $\mathrm{t}$ & $\mathrm{P}$ \\
\hline \multirow{2}{*}{ Oxford Happiness Scale } & Yes & 462 & $3.62 \pm 0.88$ & \multirow{2}{*}{1.621} & \multirow{2}{*}{.105} \\
\cline { 2 - 4 } & No & 339 & $3.55 \pm 0.64$ & & \\
\hline
\end{tabular}

Table 13 displays happiness level $\mathrm{t}$ Test results with respect to participants' regular engagement in sports. Analysis shows, that there is no statistically significant difference in happiness level with respect to participants' regular engagement in sports $(p>0.05)$. Those who are regularly engaged in sports have higher scores compared to those who are not.

Table 14. Correlation test results between life satisfaction scale and Oxford Happiness Scale

\begin{tabular}{|l|l|l|l|}
\hline \multicolumn{2}{|l|}{ Scales } & 1 & 2 \\
\hline \multirow{3}{*}{ Life Satisfaction Scale } & $\mathrm{R}$ & 1 & \\
\cline { 2 - 5 } & $\mathrm{P}$ & & \\
\hline \multirow{3}{*}{ Oxford Happiness Scale } & $\mathrm{R}$ & .379 & 1 \\
\cline { 2 - 5 } & $\mathrm{P}$ & $.000^{* *}$ & \\
\hline
\end{tabular}

Table 14 displays Pearson correlation $\mathrm{t}$ Test results, which was applied to observe whether there is a relationship between Oxford happiness scale and life satisfaction scale. Test results show that there is a positive and significant relationship between life satisfaction scale and happiness scale $(\mathrm{p}<0.05)$.

\section{Discussion}

In line with the findings of the study, which aimed at investigating and determining the relationship between life satisfaction and happiness level of university students by different factors, it has been observed, that life satisfaction and happiness level of participants has a positive correlation.

Evaluating the study results within the scope of life satisfaction scale, a significant difference has been observed with respect to age and regular engagement in sports parameters. 


\section{$\Lambda$ Macrothink}

Examining the body of literature, we find that in the study conducted by Gülcan and Nedim Bal (2014), which surveys the influence of optimism on happiness and life satisfaction in young adults, in the study conducted by Dost (2007), which surveys life satisfaction of university students by various parameters, and in the study conducted by Recepoğlu (2013), which surveys the relationship between life satisfaction and attitude towards teaching as a profession of prospective teachers a significant difference has been observed with regards to participants' gender parameter. These results and the result of our study do not match. With respect to age parameter, in the study conducted by Gülcan and Nedim Bal (2014) a significant difference has been observed. The results of this study have parallels with ours but our study does not have parallels with the study conducted by Recepoğlu (2013). Evaluating findings regarding life satisfaction with respect to department and grade parameters, it has been observed that life satisfaction level of students, who study "Recreation," have higher scores when compared to students in other departments, and that "Sophomores" have higher scores when compared to students in other grades. But no significant difference has been observed with respect to these results. In the study conducted by Kalfa (2017), which surveys life satisfaction and leisure time satisfaction of sports sciences and faculty of education students, the results obtained by grade parameter do not match with our results. When we take a look at participants' life satisfaction with respect to their departments, it might be suggested that life satisfaction level of students is irrespective of department satisfaction. Evaluating the findings regarding life satisfaction of participants who are regularly engaged in sports, it has been observed that participants who are engaged in sports have higher scores than those who are not.

Evaluating the findings regarding happiness, which is the other focus of our study, we observe significant difference with respect to gender, department, grade and department satisfaction. The results of the study conducted by Aksoy et al. (2017), which surveys happiness and modesty level of university students, and of the study conducted by Demir and Murat (2017) which surveys happiness, optimism, meaning of life and life satisfaction of prospective teachers, and the results of our study do not match with respect to gender parameter.

With respect to age parameter, no significant difference has been observed in participants' happiness levels. This result has parallels with the study conducted by Aksoy et al. (2017) but doesn't match with the result of the study conducted by Gönener et al. (2017). It has been found that the happiness level of students who study "Recreation" is higher than those who study other subjects. In the study conducted by Gönener et al. (2017), which surveys the psychological wellbeing and happiness level of Kocaeli University sports sciences faculty students, no difference has been observed with respect to department parameter. Students, however, who study sports management have higher scores than students studying other subjects. The results of this study and ours do not match. Evaluating the findings with respect to grade parameter, we observe that the happiness level of "Sophomores" is higher than that of students in other grades. The results of our study do not match with those of the study conducted by Gönener et al. (2017), but has parallels with the results of the study conducted by Aksoy et al. (2017). When we take a look at the results with respect to department 
satisfaction, we observe that participants, who are satisfied with their departments, have a higher level of happiness when compared to participants who are not satisfied with their departments. It has been observed, that there is no significant difference in happiness level of participants, whether they are regularly engaged in sports or not.

Consequently, it has been determined life satisfaction and happiness level of students vary with respect to different parameters. It has been concluded that the higher life satisfaction is, the higher the level of happiness.

\section{References}

Aksoy, A. B., Aytar, A. B., \& Kaytez, N. (2017). Üniversite Öğrencilerinin Mutluluk ve Alçakgönüllülük Düzeylerinin Bazı Değişkenlere Göre İncelenmesi. Kastamonu Ĕ̆itim Dergisi, 25(3), 1123-1137.

Appleton, S., \& Song, L. (2008). Life satisfaction in urban China: Components and determinants. World Development, 36, 11. https://doi.org/10.1016/j.worlddev.2008.04.009

Argyle, M., Martin, M., \& Crossland, J. (1989). Happiness as a function of personality and social encounters. In J. P. Forgas, \& J. M. Innes (Eds.), Recent advances in social psychology: An international perspective (pp. 189-203). Amsterdam: North Holland, Elsevier Science.

Çakıcı, S. (2015). Kutadgu Bilig'de mutluluk ile ahlak ilişkisi (psikososyal bir analiz). Yüksek Lisans Tezi, Eskişehir Osmangazi Üniversitesi Sosyal Bilimler Enstitüsü.

Demir, R., \& Murat, M. (2017). Öğretmen Adaylarının Mutluluk, İyimserlik, Yaşam Anlamı ve Yaşam Doyumlarının İncelenmesi. Uluslararası Toplum Araştırmaları Dergisi, 7(13), 349-378. https://doi.org/10.26466/opus.347656

Diener, E. (1984). Subjective well-being. Psychological Bulletin, 95(3), 542-575. https://doi.org/10.1037/0033-2909.95.3.542

Diener, E., Emmons, R. A., Larsen, R. J., \& Griffin, S. (1985). The Satisfaction with Life Scale. Journal of Personality Assessment, 49(1), 71-75. https://doi.org/10.1207/s15327752 jpa4901_13

Diener, E., Suh, E. M., Lucas, R. E., \& Smith, H. L. (1999). Subjective well-being: Three decades of progress. Psychological Bulletin, 125(2), 276-302. https://doi.org/10.1037/ 0033-2909.125.2.276

Dikmen, A. A. (1995). İş Doyumu ve Yaşam Doyumu İlişkisi. A.Ü. Siyasal Bilgiler Fakültesi Dergisi, 50(3-4), 115-140. https://doi.org/10.1501/SBFder_0000001851

Doğan, T., \& Akıncı Çötok, N. (2011). Oxford mutluluk ölçeği kısa formunun türkçe uyarlaması geçerlik ve güvenirlik çalışması. Türk Psikolojik Danışma ve Rehberlik Dergisi, $4(36), 165-172$.

Dost, M. T. (2007). Üniversite Öğrencilerinin Yaşam Doyumunun Bazı Değişkenlere Göre İncelenmesi. Pamukkale Üniversitesi Eğitim Fakültesi Dergisi, 22(2), 132-143. 


\section{I Macrothink}

Journal of Educational Issues

ISSN 2377-2263

2019, Vol. 5, No. 1

Durak, M., Șenol Durak, E., \& Gençöz, T. (2010). Psychometric properties of the satisfaction with life scale among Turkish university students, correctional officers, and elderly adults. Social Indicators Research, 99(3), 413-429. https://doi.org/10.1007/s11205-010-9589-4

Gönener, A., Öztürk, A., \& Y1lmaz, O. (2017). Kocaeli Üniversitesi Spor Bilimleri Fakültesi Öğrencilerinin Mental (Psikolojik) İyi Olma Düzeylerinin Mutluluk Düzeylerine Etkisi. Sportif Bakış: Spor ve Eğitim Bilimleri Dergisi, 4(1), 44-55.

Gülcan, A., \& Nedim Bal, P. (2014). Genç Yetişkinlerde İyimserliğin Mutluluk ve Yaşam Doyumu Üzerindeki Etkisinin İncelenmesi. Asya Öğretim Dergisi, 2(1), 41-52.

Hills, P., \& Argyle, M. (2002). The Oxford Happiness Questionnaire: a compact scale for the measurement of psychological well-being. Personality and Individual Differences, 33, 1073-1082. https://doi.org/10.1016/S0191-8869(01)00213-6

Kalfa, S. (2017). Spor Bilimleri ve Ĕ̆itim Fakültesi Öğrencilerinin Yaşam Doyumu ve Serbest Zaman Doyumunun Incelenmesi (Uşak Üniversitesi Örneği). Muğla Sitk1 Koçman Üniversitesi Sosyal Bilimler Enstitüsü. Yüksek Lisans Tezi.

Karasar, N. (2012). Bilimsel araştırma yöntemi. Ankara: Nobel Akademik Yayıncılık.

Lyubomirsky, S. (2007). The how of happiness: A scientific approach to getting the life you want. New York: The Penguin Press.

Recepoğlu, E. (2013). Öğretmen Adaylarının Yaşam Doyumları ile Öğretmenlik Mesleğine Ilişkin Tutumları Arasındaki Ilişkinin İncelenmesi. Hacettepe Üniversitesi Eğitim Fakültesi Dergisi, Özel Sayl, 1, 311-326.

Ryan, R. M., \& Deci, E. L. (2001). On happiness and human potentials: A review of research on hedonic and eudaimonic well-being. Annual Review of Psychology, 52, 141-166. https://doi.org/10.1146/annurev.psych.52.1.141

Sahranç, Ü. (2007). Stres Kontrolü, Genel Öz-Yeterlik, Durumluk Kaygı ve Yaşam Doyumuyla İlişkili Bir Akış Modeli (Doktora Tezi, GÜ Ĕ̆. Bil. Enst., Ankara).

Shin, D. C., \& Johnson, D. M. (1978). Avowed happiness as an overall assessment of the quality of life. Social Indicators Research, 5, 475-492. https://doi.org/10.1007/BF00352944

Veenhoven, R. (1996). The Study of Life Saticfaction. In W. E. Saris, R. Veenhoven, A. C. Scherpenzel, \& B. Butting (Eds.), A Comparative Study of Saticfaction with Life in Europe (pp. 11-48). Budapest: Eötvös University Press.

\section{Copyright Disclaimer}

Copyright for this article is retained by the author(s), with first publication rights granted to the journal.

This is an open-access article distributed under the terms and conditions of the Creative Commons Attribution license (http://creativecommons.org/licenses/by/3.0/). 